\title{
Fatalism in Co-evolutionary Urban Planning: Experiences from Infill Planning in Finland
}

Hanna Kosunen ${ }^{\mathrm{a} *}$ and Sari Hirvonen-Kantola ${ }^{\mathrm{a}}$

${ }^{a}$ Oulu School of Architecture, University of Oulu, Oulu, Finland

*corresponding author: Hanna Kosunen, hanna.kosunen@oulu.fi

This is an Accepted Manuscript of an article published by Taylor \& Francis in Planning Practice \& Research on 27/03/2020, available online:

http://www.tandfonline.com/10.1080/02697459.2020.1743922 


\title{
Fatalism in Co-evolutionary Urban Planning: Experiences from Infill Planning in Finland
}

\author{
While urban planning must deal with complexity, considering planning as an \\ activity with uncertain outcomes is challenging. This paper explores how urban \\ planning may both proactively motivate development and adapt to change. We \\ view such planning as co-evolutionary, and conceptualize it further by utilizing \\ Cultural Theory, and building on a case study of infill planning in Oulu, Finland. \\ We conclude that while the three active rationales from Cultural Theory can \\ motivate urban development, the fourth, passive, fatalistic rationale, is also \\ needed in order to acknowledge an uncertain future. Further, we discuss three \\ challenges in using fatalism as a planning rationale.
}

Keywords: co-evolutionary planning; infill planning; planning rationale; Cultural Theory; fatalism

\section{Introduction}

Notions that urban planning must adapt to the complexity of reality are on the rise (Savini et al., 2015; Boelens \& De Roo, 2016). As pre-programmed urban development projects have often had a limited capacity to respond to the unexpected, urban planning that embraces contextual changes is called for (Giezen et al., 2014; Savini et al., 2015; De Roo \& Boelens, 2016). For example, the global economic crisis in 2008 resulted in the stagnation of many prosperous urban development projects, and generated growing interest in the capacity of urban planning to operate in uncertain situations (De Roo \& Boelens, 2016; Savini \& Salet, 2017).

This paper aims to contribute to the research on the adaptive capacity of urban planning from a proactive perspective, which has recently entered the discussion (Oosterlynck, 2011; De Roo \& Boelens, 2016). We explore a situation where planning aims to proactively develop a context considered to have opportunities for change, but the actual development opportunities are not clear, and the future is thus uncertain. 
Planning in such situations requires adaptive capacity: while planning has the power to set things in motion, an uncertain future makes us unable to foresee how a situation will develop, and should therefore leave room for change. The challenge is that urban planning is often expected to produce clearly defined planning problems and solutions, which hinders viewing planning as an activity with uncertain outcomes (Bertolini, 2010; Boelens \& Coppens, 2015; Majoor, 2015).

The question this paper seeks to explore is: "How can planning both proactively motivate urban development and adapt to change?" In the following sections, we propose that co-evolutionary urban planning (Bertolini, 2007; 2010; Boelens \& De Roo, 2016; Van Assche et al., 2017) provides grounds for that dual approach, and conceptualize it further utilizing Cultural Theory (Thompson et al., 1990) and its concept of 'clumsy solutions' (Verweij et al., 2006). We then present our research strategy, and the analysis of our empirical material, comprising a longitudinal case study of infill planning activities in Kaukovainio, a suburb of Oulu, Finland. We conclude that in co-evolutionary urban planning, the three active planning rationales derived from Cultural Theory enable the exploration of future scope for action, while the fourth, passive, fatalistic rationale is needed to acknowledge that the future is uncertain. We also present three challenges in using fatalism as a planning rationale and discuss ways to overcome them. The research shows that urban planning leading to unexpected outcomes should not be considered a failure, but the result of co-evolution.

\section{Co-evolutionary Urban Planning}

The idea of co-evolution originates from ecology, but is increasingly applied to social theories, also to the field of urban planning (De Roo \& Boelens, 2016). Co-evolution can be viewed as the transformation a system undergoes to achieve optimal functionality and structure, both internally and with its context (Holling, 2001; De Roo 
\& Boelens, 2016). It therefore explains the change process, where the included elements shape each other in iterative rounds, each change building on the preceding one (Van Assche et al., 2017). In applying the concept of co-evolution to social systems, human abilities, such as learning and foresight, can intentionally guide change (Holling, 2001; Davoudi et al., 2013). Consequently, the concept of co-evolution in the social context is not value-free but always affected by human intention, in contrast to the ecology view where co-evolution is understood in more analytical terms (Porter \& Davoudi, 2012). Thus, while recognizing planning as co-evolutionary can help acknowledge the uncertainty of reality and view transformation and dynamism as normal, the direction of transformation should be critically assessed (Porter \& Davoudi, 2012).

As implied, in co-evolutionary urban planning, the plan as an understanding of the situation, and the situation itself, evolve incrementally with mutual influence (Boelens \& De Roo, 2016; Van Assche et al., 2017). Ideally, planning would constantly adapt to real-world events, while tweaking development in the desired direction (Bertolini, 2007; 2010; Boelens \& De Roo, 2016). It is suggested that the coevolutionary approach should be adopted in uncertain environments, as it allows actors to experiment with solutions as the situation unfolds (Bertolini, 2007; 2010). For example, the discussion on evolutionary resilience in urban planning describes it as an ability to transform with the changing context towards a more desirable future, instead of applying responses that resist change (Davoudi, 2012; Davoudi et al., 2013).

Arguably the less explored side of co-evolutionary planning is where planning develops context (De Roo \& Boelens, 2016). The question is then not only about how planning may become more flexible, but also how it may guide action in an uncertain future (Savini et al., 2015; De Roo \& Boelens, 2016; Van Assche et al., 2017). The Mixed-scanning approach (Etzioni, 1967) has suggested that switching between the 
strategic and operational levels of planning would enable plans' incremental development while retaining proactiveness. More recently, the evolutionary governance theory (Beunen et al., 2016; Van Assche et al., 2017) has suggested that the proactiveness of co-evolutionary planning lies in its ability to create goal dependencies: while past and present partly determine the situations that will unfold, planning can affect the future by proposing visions and plans as a point of reference. These may enable collective action towards the agreed urban development goal (Savini et al., 2015), or act as a catalyst for opposition and inspire alternative developments (Van Assche et al., 2017). This demonstrates that goal dependencies created by planning always have an impact on reality, even if the plans themselves are not implemented (Van Assche et al., 2017).

However, adapting to change and attempting simultaneously to guide it is cognitively and operationally challenging (March, 1991; Majoor, 2015). What is more, since urban planning has significant impacts on society, it is often expected to produce clearly defined planning problems and solutions (Bertolini, 2010; Majoor, 2015).

Correspondingly, actors often avoid experimenting with planning solutions (Boelens \& Coppens, 2015), especially after the initial, visionary stage of the planning process (Majoor, 2015). Thus, the challenge of co-evolutionary planning is that while plans should leave room for contextual changes, they seemingly prefer some future developments over others. Thus, there is a risk that co-evolutionary planning proactiveness is misunderstood: planning is considered a failure, if it does not lead to the predefined outcomes. Next, to garner insights on how this challenge could be resolved, we turn to Cultural Theory and its concept of clumsy solutions.

\section{Cultural Theory and Urban Planning}

Cultural Theory describes four perceptions of reality that are present in all social 
situations. Each perception delivers a way to understand a problem and propose a solution (Thompson et al., 1990). However, none of the rationales is able to solve societal problems alone, since they only partially capture reality (Thompson et al., 1990; Verweij et al., 2006). Thus, the rationales should be combined in solving complex problems (Verweij et al., 2006). For urban planning, Cultural Theory has been proposed as a way to conceptualize and understand the polyrationality of planning situations (Davy, 2008; 2012), and manage expectations of the diverse rationales' utilization (Hartmann, 2011; 2012). Cultural Theory has also been employed to distinguish political perspectives in urban policy-making (Hendriks, 1999), for complementary approaches to spatial policies (Hartmann \& Hengstermann, 2014), motivations for participation in planning processes (Hartmann, 2012; Kuusisto-Arponen et al., 2014), and urban design principles that enhance diversity in cities (Schmitt \& Hartmann, 2016).

Cultural Theory originates from the work of anthropologist Mary Douglas, who proposed that human perceptions of reality depend on two dimensions, grid and group (Douglas, 1973; 1978). The grid dimension denotes how individuals position themselves in relation to externally-imposed control, whereas the group dimension denotes their willingness to belong to a group or act on their own (Douglas, 1978; Mamadouh, 1999). Grid-group combinations result in four cultures or rationales that individuals use when interpreting reality: hierarchism, egalitarianism, individualism, and fatalism (Thompson et al., 1990). In the following, we discuss how these rationales have been connected to urban planning, as presented in Figure 1. [Figure 1. near here] Hierarchism is a perception of reality with high dependency on external rules and strong willingness to belong to a group (Thompson et al., 1990). Thus, it suggests problems can best be addressed by agreeing on common rules (Verweij et al., 2006). 
For urban planning, hierarchism is the perspective where regulation and control are considered necessary to guide spatial development (Hartmann, 2012; Hartmann \& Hengstermann, 2014). The ideal city is well-ordered and guided by the expert knowledge of urban planners (Davy, 2008; 2012). However, employing the other rationales, a city such as that may appear rigid (Davy, 2008).

Egalitarianism represents low trust in external rules but high willingness to belong to a group (Thompson et al., 1990). For problem-solving, reaching consensus within a group is valued, but external hierarchy viewed as restrictive (Verweij et al., 2006). Also, the free operation of markets is considered a threat, because it ignores the need for joint action in answering societal problems (Verweij et al., 2006). In urban planning, egalitarianism has been connected to approaches that value participatory decision-making, such as communicative planning (Hendriks, 1999; Hartmann \& Hengstermann, 2014), and approaches that view local initiatives as a resource in urban development (Davy, 2008; 2012). However, the other rationales may view egalitarian planning as exclusive, serving only those willing to agree with the group (Davy, 2008).

Individualism is a perception of reality with low dependency on both external rules and other people (Thompson et al., 1990). In the individualistic worldview, problems are best solved when everyone is free to experiment and innovate without external restrictions (Verweij et al., 2006). The ideal city for individualists provides opportunities to take risks and generate revenues (Davy, 2008), and the rationale has therefore been associated with urban planning that encourages market-led development projects (Hendriks, 1999; Davy, 2012; Hartmann \& Hengstermann, 2014). Those not agreeing with this rationale may regard the individualistic city as unequal (Davy, 2008).

Finally, fatalism is a worldview with a high grid-dimension and therefore is resigned to externally imposed control, but due to the low group-dimension believes 
affecting the controlling structures is impossible (Thompson et al., 1990). A fatalist thinks that 'what happens (or has happened) in some sense has to (or had to) happen' (Solomon, 2003, p. 435). Therefore, there is no reason to plan-reality must be taken as is (Thompson et al., 1990; Verweij et al., 2006). In urban planning, Hendriks (1999) proposes that fatalism represents a feeling of powerlessness regarding urban challenges. Hartmann (2012) sees the fatalistic rationale as inherent to those who do not believe in controllability of the world, and therefore do not participate in urban planning. Hartmann and Hengstermann (2014) connect fatalism with planning that views the world as too complex to handle, and manages projects as ad-hoc collaborations with no strategic intention. Davy $(2008 ; 2012)$ describes the fatalist city as a relaxed city that accepts also unintended urban developments. However, the other rationales may view fatalism as indifferent to the need for targeted actions in societal problem-solving (Davy, 2008).

\section{Four Rationales as the Elements of Co-evolutionary Planning}

Cultural Theory indicates that all four rationales are present in any social situation, and each provides a partial explanation for the external reality (Thompson et al., 1990). It has thus been suggested that combining the rationales would result in a 'clumsy solution' that is compatible with various problem definitions (Verweij et al., 2006). Clumsy solutions are needed to address complex societal challenges that cannot be resolved through one rationale alone (Verweij et al., 2006). In urban planning, constructing a clumsy solution requires our recognition that planning situations are viewed through multiple rationales (Davy, 2008; 2012). The expectations the different rationales bring to the planning situation must thus be consciously managed (Hartmann, 2011; 2012). 
The challenge of constructing a clumsy solution is that the rationales tend to overpower each other, because viewing the problem from one rationale's perspective is irrational to another (Verweij et al., 2006). Consequently, the emphasis on different rationales in social situations tends to change over time and space (Thompson et al., 1990). However, ignoring any of the four rationales would result in a non-clumsy solution; even if some of the rationales are not present when the solution is constructed, they will eventually emerge (Verweij et al., 2006). Therefore, clumsy solutions should recognize the complexity of the problem, and view the four rationales as complementary ways to solve it (Verweij et al, 2006).

Of the four rationales, hierarchism, egalitarianism and individualism are active and attempt to influence the course of events (Thompson et al., 1990; Mamadouh, 1999). In a clumsy solution, hierarchism proposes that structure and control are needed to solve the problem. Egalitarianism highlights the importance of a mutually shared problem definition, and individualism suggests the problem should be addressed by experimenting with competing solutions. In contrast, fatalism deviates from these three rationales due to its passive nature: it does not seek to affect the outside world and considers it intrinsically uncontrollable (Thompson et al., 1990; Mamadouh, 1999; Verweij et al., 2006). Consequently, fatalism has received sparse attention as a rationale to solve societal problems, and because of its tendency to inaction has been said to undermine the efforts of the three active rationales (Hood, 2002). Similarly, in urban planning, the fatalistic rationale has been considered to produce apathy (Hendriks, 1999), withdrawal from planning processes (Hartmann, 2012), or ad-hoc behavior (Hartmann \& Hengstermann, 2014).

Given that all the rationales must be present in a clumsy solution, fatalism provides important insights into problem-solving. Verweij and colleagues (2006) 
suggest the wisdom of fatalism lies in not acting in uncertain situations, where actions' consequences cannot be known. Fatalism may also be viewed as a reservoir that creates space for the other rationales to emerge (Thompson et al., 1990). Hood (2002), Hartmann and Hengstermann (2014), and Thompson and Beck (2015), observe that fatalism has an important role in reminding us that things do not always go as planned, and could therefore provide a strategy for coping with uncertainty. Similarly, in considering the fatalistic rationale in urban planning, Davy $(2008 ; 2012)$ proposes its value lies in acknowledging that not everything can be controlled by planning. Hartmann (2012) observes that while the fatalist idea of non-intervention could indeed be valuable in some cases, it has been widely neglected by planners.

We propose that co-evolutionary urban planning would benefit from the clumsy solution concept, where the four rationales are combined so that the solution endures contextual changes. This would allow for the application of planning rationales that are appropriate for the current situation, while preserving the opportunity to incorporate other rationales, if the situation changes (see also Hartmann, 2012). However, this is a challenging point of departure for urban planning, since it requires acknowledging that the solution is not yet fully available, a stance which leaders and professionals typically avoid (Schön, 1983; Grint, 2010). A further challenge is the controversial understanding of the relevance of fatalism to problem-solving. We now turn to our empirical study to gain further insight into these challenges.

\section{Four Rationales in the Infill Planning of the Kaukovainio Suburb}

Our case study explores infill planning activities in the Kaukovainio suburb of Oulu, Finland. Kaukovainio is one of the Finnish suburbs built outside city centers from the 1940s to 1970s. In current Finnish urban policies, infill development in the suburbs is considered to advance sustainable urban development (Ministry of the Environment, 
2014). Suburbs have infill development potential, especially due to their loose urban structure, advantageous location, and existing infrastructure and services that could be put to more efficient use. Therefore, Finnish cities have the motivation to proactively plan for new infill development in their suburbs. However, this is a challenging task: as infill planning operates in the extant urban context, it has to consider the aims of various actors and enable development resulting from their intentions. That calls for proactive urban planning which is able to cope with uncertainty. We suggest these features make

infill planning in Finnish suburbs a suitable case with which to explore co-evolutionary urban planning.

In studying infill planning activities in Kaukovainio, we have employed longitudinal case study research, which is considered a suitable strategy for the examination of change (Yin, 2014). Our analysis identifies three phases of infill planning in Kaukovainio. The first is the Kaukovainio general infill development plan (2010-2013), an overall infill development scheme for the area. The second is the Kaukovainio Center infill development project (2012-2017), a strategic project where the local shopping center was replaced with new housing and commercial functions. The third phase is Kaukovainio as a part of a national urban renewal program (2013-2015), where socially-oriented neighborhood development activities were enacted to complement infill development activities.

The empirical material comprises 16 interviews of urban planners and other relevant actors in the case study (Appendix 1), and the related planning documents (Appendix 2). Due to the exploratory nature of our research question, we employed a narrative interview format, where the discussion was guided by the interviewees' reflections on past events (Kvale \& Brinkmann, 2009). The role of the interviewer was to call for a story, and structure a coherent plot together with the interviewee (Kvale \& 
Brinkmann, 2009). We also organized a workshop for the Kaukovainio urban renewal program steering group, which reflected on the different phases of Kaukovainio infill

planning. These multiple materials enabled us to employ the source triangulation case study method (Yin, 2014).

The analysis followed the thematic analysis and coding technique, where data are categorized and reconstructed to capture important concepts within the data set (Coffey \& Atkinson, 1996). We identified planning rationales based on hierarchism, egalitarianism, individualism, and fatalism in each planning phase (see Figure 1). We now present our analysis in more detail.

\section{Kaukovainio General Infill Development Plan: Integrating the Three Active Rationales}

In its master plan, accepted in 2016, the City of Oulu identified certain suburbs as strategic areas for infill development. Kaukovainio is the first where the City has also made a general plan for infill development. This plan is strategic and long-term in nature, but not juridically binding. Its purpose is to guide, coordinate and prioritize prospective infill development projects in the area. The plan also identifies historical and environmental values in the area that should be protected. The City considered it important to compile a general plan for Kaukovainio's development, before proceeding with individual projects. There was a concern that without a general plan, some of the area's infill development potential might be lost.

For the infill development plan, the City organized participatory planning workshops in cooperation with the Kaukovainio District Board, a local organization run by the residents. The City's explicit aim was to involve residents and local actors in the planning process, to establish a mutual ambition for the neighborhood's development. The participatory planning workshops evaluated Kaukovainio's current strengths and 
weaknesses, and proposed desirable functions and locations for new urban development. The workshops attracted many participants and generated enthusiasm for the future development.

The infill development plan was also considered to motivate private infill development projects in the area. The interviewees highlighted that the City alone could not decide on the implementation of infill development, and making a general plan could attract private infill projects by portraying Kaukovainio as a developing area. The general plan was also considered to help with the synchronization of diverse projects.

In sum, the Kaukovainio infill development plan could be characterized as a combination of hierarchist, egalitarian and individualistic rationales. From the hierarchist perspective that seeks to structure collective action (Verweij et al., 2006), the purpose of the plan was to discover the area's overall infill potential. The egalitarian rationale that values solving problems at the local level (Verweij et al., 2006), was utilized by compiling the plan together with the residents and local actors. The plan also attempted to motivate private infill development projects by making visible the area's development potential. This implies employing the individualistic rationale, which seeks to solve problems through innovation in competitive environments (Verweij et al., 2006).

The fatalistic rationale was given little consideration at this phase, even though it has a role to play in a clumsy solution (Verweij et al., 2006). The most fatalistic notions were presented by some interviewees who considered the infill development plan merely an enabling framework. This perspective, however, contrasted with the other rationales that sought to actively motivate infill development. For instance, in the participatory planning workshops, potential threats to the future development of Kaukovainio, such as population decline, withdrawal of public and private services, and 
decreased attractiveness of the area, were framed as something that could be prevented by infill development. The fatalistic worldview, therefore, was incompatible with the combination of the other three rationales, which stated that action must be taken to prevent unwanted development.

\section{Kaukovainio Center Project: An Encountering with Fatalism}

In the aforementioned Kaukovainio infill development plan, potential was discovered in selected greenfield areas, plots rented to private housing co-operatives, and most importantly Kaukovainio Center in the vicinity of an old, rundown shopping mall. The general opinion in the participatory planning workshops was that the current decay of the shopping mall had a negative impact on the entire area, and should be developed.

Therefore, infill planning activities proceeded with the preparation of a new local detailed plan for Kaukovainio Center, where the old mall was to be replaced by a new supermarket and housing projects. The project parties were the City of Oulu, shareholders of the old mall, a construction company acting as their consultant, the local parish, and the City's own housing rental company. The local detailed plan was then prepared jointly by the parties. The City played a central role in the project, not only as the planning authority that had the monopoly to draw up the final plan, but also as a mediator between the project participants. As the major landowner, the City also had the possibility to offer some sites and greenfield areas for development, and thereby support the overall development comprising smaller private projects.

The City also prioritized Kaukovainio Center over other potential infill sites found in the general infill development plan. The idea was that the Kaukovainio Center project would kick-start development in the neighborhood and have a positive impact on its image, thereby improving the starting points of all future infill projects. In addition, it was considered important that there would only be a limited number of 
Kaukovainio infill development projects ongoing at a time, to regulate market demand for the projects. While Kaukovainio was considered to have development potential due to its location nearby the city center and its identity as a housing area close to nature, apartment prices in the area were lower than in the neighboring areas.

Framing the Kaukovainio Center project as the most important way to develop the area implies limiting the planning rationales to hierarchism and individualism. The individualistic rationale was utilized in the sense that area development was now based on commercial infill development. This was complemented by the hierarchist rationale that prioritized the Kaukovainio Center project over the other potential infill projects. Indeed, while the individualist rationale considers control undesirable, it is often dependent on the security provided by hierarchist regulation (Thompson et al., 1990).

However, this combination of rationales later encountered challenges when the Kaukovainio Center project was delayed. The interviewees had many interpretations for the delay. On one hand, the overall economic situation had changed, and the development opportunity was not as interesting for private parties as earlier. On the other, the large size and complexity of the project required more time than had been expected. From this perspective, the City and local actors had done their best to progress the development by preparing the general infill development plan, and the length of the process was normal for a large urban development project of its kind. This implies viewing the situation through the fatalistic rationale, where the potential to affect the course of events is considered limited (Verweij et al., 2006).

Yet, for the previous framing of the planning problem, the delay was problematic. The general infill development plan had created enthusiasm for the future development of the area, especially among residents. Paradoxically, because Kaukovainio Center was prioritized to be the first infill development project, its slow 
progress now seemed to halt the development of the whole area. Some interviewees assessed that the delay could even be counterproductive to Kaukovainio's image. From this perspective, the combination of hierarchist and individualistic rationales appeared insufficient for the changed situation. It also implies that the fatalistic rationale, which accepts the limited potential to affect the course of events, was only partially embraced by participants. Tolerating the changed circumstances contradicted the initial planning situation, where non-development was framed as a threat.

\section{Kaukovainio Urban Renewal Program: Coping with the Changed Situation}

Parallel to the Kaukovainio Center project, the City enrolled Kaukovainio in a national urban renewal program for housing areas. This was considered to reinforce the suburb's image as a developing area. The program was also considered to diversify the scope for development, as the general infill development plan and the Kaukovainio Center project focused mostly on improving the physical environment and bringing new inhabitants to the area. The urban renewal program provided opportunities to develop public services, citizen participation and the suburb's identity, as well as to support private housing cooperatives' renovations in the area.

During the urban renewal program, improvements regarding public spaces, such as green areas, parks, playgrounds and walking and cycling routes were planned together with the local elderly, children, youngsters and multicultural groups. New ways of using public spaces and services were also originated. Instructions and guidance regarding building renovation, green infrastructure improvement and infill development opportunities were provided to housing co-operatives. In addition, local grassroots activities, such as a community art project and an annual neighborhood festival were considered a contribution to area development. 
While the urban renewal program was originally viewed as complementary to the Kaukovainio Center project, it was later assessed successful in progressing the development activities when the Kaukovainio Center project was delayed. Especially the local initiatives, such as the neighborhood festival, were appreciated because they engaged residents in the development activities and communicated that something interesting was happening. The planning situation's new framing thus placed more emphasis on the egalitarian rationale. However, the interviewees were still concerned about the delay of the Kaukovainio Center project, and considered the urban renewal program alone was not a sufficient way to proceed with area development. Therefore, while the fatalistic rationale was utilized to acknowledge that plans do not always proceed as intended, the complementary activities were not fully appreciated either.

\section{Results and Discussion}

In this paper, we have proposed that the proactive and adaptive features of coevolutionary planning could be conceptualized further by utilizing Cultural Theory and its concept of clumsy solutions, where four rationales are combined to endure contextual changes. Our case study demonstrates how the three active rationales can be understood as proactive planning rationales seeking to affect the planning situation. However, we also observed challenges in combining the passive, fatalistic rationale with the active worldviews that attempt to shape the course of events. We propose that contrasting understandings on the fatalistic rationale provide opportunities and challenges for co-evolutionary urban planning, as presented in Table 1. [Table 1. near here].

\section{Fatalism is not Embraced Because of its Passiveness}

First, embracing fatalism in urban planning might be challenging, because the three 
active rationales may seem more suitable for motivating urban development. As the essence of urban planning is to transform the current situation into a more desirable one (Albrechts, 2011; Savini et al., 2015, van Assche et al., 2017), the fatalistic rationale in its passiveness might be the counter-intuitive rationale for mainstream planning. Our case study demonstrates this by showing how fatalism was not compatible with the other rationales in the Kaukovainio general infill development plan, where the aim was to proactively motivate infill development in the area. The hierarchist rationale was used to set a framework for the overall development, the egalitarian rationale to establish a shared vision, and the individualistic rationale to motivate private projects. For these rationales, the non-implementation of infill development was a threat. This contrasted with the fatalistic understanding, which considered the plan merely an enabling framework, with uncertain implementation prospects.

However, we argue that recognizing the fatalistic rationale in our urban development case could have improved its co-evolutionary features. In making the general infill development plan, admitting that the intended development might not actualize as planned could have helped identify the risks of locking into only one development scenario, and inspired exploration of alternative development scenarios (c.f. Bertolini, 2010; Majoor, 2015). We thereby suggest that recognizing the fatalistic rationale would improve the capacities of planning to co-evolve with changing situations. More specifically, this would mean appreciating the high grid-dimension of fatalism, which states that the future cannot be influenced or created by human agency, but is also affected by unknown causes (Eilstein, 1997). We assume this high griddimension is the feature that is appreciated also by Hood (2002), Davy (2008; 2012), Hartmann (2012), Hartmann and Hengstermann (2014), and Thompson and Beck (2015), when they discuss fatalism as a way to deal with uncertainty and complexity. 


\section{Fatalism Results in Inaction}

The second challenge is that the passive fatalistic worldview often results in inaction. Also, this feature of fatalism is recognized in the planning literature that discusses Cultural Theory: since fatalists view attempts to solve societal problems as unreasonable, they tend to withdraw from urban planning (Hartmann, 2011; 2012; Kuusisto-Arponen et al., 2014), and fatalism often results in apathy when facing urban challenges (Hendriks, 1999). In our case study, this was exemplified by the views that considered the Kaukovainio Center project delay acceptable and unavoidable. We suggest these views connect especially with the low group-dimension of fatalism, which views collective action as unreasonable (Thompson et al., 1990). We argue that this dimension of fatalism is somewhat contradictory to urban planning, which explicitly seeks to invoke collective action to solve urban problems.

However, we argue this is not a reason to abandon fatalism as a planning rationale. Rather, to retain the ability of planning to be proactive, we suggest the inherent passiveness of fatalism should be overcome by complementing it with other rationales. Our case study revealed that the three active rationales considered the Kaukovainio Center project delay a threat, and the Kaukovainio urban renewal program and egalitarian rationale an alternative way to proceed with area development. Coevolutionary urban planning therefore needs the other rationales, to overcome fatalism's tendency not to act when the situation changes. Our suggestion comes close to the idea proposed by Thompson and colleagues (1990), who considered fatalism a reservoir that makes room for alternative solutions to emerge.

\section{Fatalism is Viewed as Indifference}

The third challenge is that unclearly communicated benefits of fatalism may undermine 
its usability as a planning rationale. While the three active rationales are needed to accompany the fatalistic rationale, they tend to view it as indifferent to issues they consider important (Davy, 2008). This was demonstrated in our case study where the urban renewal program, focusing on small, local urban development activities, was not valued as a sole measure for area development, because the original framing of the planning problem had created strong expectations for infill development. Davy (2008) proposes that while the situations where planning rationales change are confusing, they also create new opportunities for urban development. However, our case study exemplifies that such opportunities may not be appreciated, if the participants hold to the previous problem definition.

Consequently, we suggest fatalism should be recognized in a planning process not as being indifferent to collective action, but informed about the possibility of the unexpected. In our case study, acknowledging and communicating this more clearly could have helped appreciate alternative measures in the neighborhood development. Thereby, we agree with Hartmann (2012) that managing the polyrationality of planning situations enhances the capacity of planning to deal with complex reality. In addition, we wish to highlight that fatalism, which is often neglected in the literature on Cultural Theory, must be explicitly considered and communicated along with the three active rationales.

\section{Conclusions}

In sum, we suggest that in co-evolutionary urban planning, fatalism should be skillfully integrated with the three active rationales. This would entail recognizing the high grid-dimension of fatalism as an opportunity to acknowledge future uncertainty. In co-evolutionary urban planning, fatalism thus complements the other rationales by demonstrating that none of the proposed solutions may be applicable in the 
future. The low group-dimension of fatalism, in turn, should be recognized as a challenging feature that views collective action as unreasonable, and is thereby a somewhat contradictory rationale for urban planning, which seeks to change the current situation into something better. Thus, fatalism cannot be utilized alone as a planning rationale, but must be accompanied by the three active rationales. To recognize the opportunities and challenges provided by fatalism, we suggest they should be explicitly communicated in the planning process.

Our findings reveal the relevance of fatalism, which has previously been interpreted in diverging ways, or even ignored in Cultural Theory based planning discussions. Our conceptualization recognizes the opportunities and challenges of fatalism as a planning rationale, and helps formulate clumsy solutions in urban planning. Our research therefore advances discussions that indicate the abilities of polyrational planning to cope with changing situations (Davy, 2008; 2012; Hartmann, $2011 ; 2012)$. We believe that elaborating the meaning of fatalism is relevant now that the abilities of urban planning to operate in complex realities are increasingly discussed.

Our research also provides insights for co-evolutionary planning. It should be recognized that the fatalistic rationale could help grasp the idea that urban planning which leads to unexpected outcomes should not be considered a failure, but an inherent feature of planning operating in an uncertain environment. This notion could help introduce co-evolutionary forms of planning that do not measure the performance of urban plans just in terms of their implementation, but of their ability to co-evolve with the situation (Beunen et al., 2016). It could also inspire urban planning that continuously considers alternative development scenarios with their associated risks and opportunities, instead of preferring one fixed end-state over others (Bertolini, 2010; Majoor, 2015). While these practices would enhance the capacities of planning to cope 
with uncertainty, the challenge is that they should also maintain a degree of reliability and security that mainstream urban planning has by far provided for different stakeholders (Majoor, 2015). We suggest that creating clumsy planning solutions that include fatalism could provide a cognitive approach towards such planning.

However, further research on how to operationalize such planning is needed. Challenges will be related to how to engage stakeholders in processes that foster continuous learning from emerging insights (Bertolini, 2010; Beunen et al., 2016), and persuade them to accept polyrational problem definitions (Verweij et al., 2006; Hartmann, 2012). A specific challenge would be that fatalists, who are unwilling to participate in collective action, would probably not be there to represent themselves. As creating a clumsy solution requires institutional arrangements where each of the rationales is heard, and the missing rationales recognized (Hartmann, 2012; Thompson \& Beck, 2015), one potential starting point to integrate fatalism into urban planning would be that planners recognize the benefits and challenges of fatalism, and introduce them into a planning process. A limitation of this research is that it does not provide much insight on this issue, as it originates from a context where fatalism was not treated as a part of a clumsy solution. More insights on how to integrate fatalism into urban planning could therefore be gained by researching contexts where fatalism is recognized.

Another potential limitation of this research is that it views the ability of planning to co-evolve with changing situations as a fundamentally positive feature that helps to view transformation and dynamism as normal (cf. Porter \& Davoudi, 2012). For instance, we suggest that considering fatalism in our case study could have helped the appreciation of local, citizen-based initiatives in neighborhood development, instead of sticking to the previous planning goals. Yet, while recognizing planning as co- 
evolutionary can help value diverse development trajectories, the direction of transformation should be critically assessed (Porter \& Davoudi, 2012). It is possible that fatalism and the co-evolutionary features of planning in general can also be used to justify development towards more exclusive or unequal goals. Therefore, another avenue for further research would be to critically examine the nature of planning objectives that fatalistic urban planning helps to achieve.

\section{Acknowledgements}

The authors wish to thank the editor-in-chief and the two anonymous reviewers for their constructive comments on this paper. The authors also wish to thank the interviewees for enabling the research.

\section{Disclosure statement}

No potential conflict of interest was reported by the authors.

\section{Funding}

This work was supported by the Emil Aaltonen Foundation under Grant [170129O].

\section{References}

Albrechts, L. (2011) Transformative practices: Where strategic spatial planning meets social innovation, in: S. Oosterlynck (Ed) Strategic spatial projects: Catalysts for change, pp. 17-25 (New York, NY: Routledge).

Bertolini, L. (2007) Evolutionary urban transportation planning: An exploration, Environment and Planning A, 39(8), pp. 1998-2019.

Bertolini, L. (2010) Coping with the irreducible uncertainties of planning: An evolutionary approach, in: P. Healey \& J. Hillier (Eds) The Ashgate research companion to planning theory: Conceptual challenges for spatial planning, pp. 413-424 (Farnham: Ashgate).

Beunen, R., Duineveld, M. \& Van Assche, K. (2016) Evolutionary governance theory and the adaptive capacity of the Dutch planning system, in: G. De Roo \& L. Boelens (Eds) Spatial planning in a complex unpredictable world of change: 
Towards a proactive co-evolutionary type of planning within the Eurodelta, pp. 98-117 (Groningen: InPlanning).

Boelens, L. \& Coppens, T. (2015) Actor-relational planning in deprived areas:

Challenges and opportunities in Luchtbal Antwerpen, Belgium, Planning Practice \& Research, 30(4), pp. 410-423.

Boelens, L. \& De Roo, G. (2016) Planning of undefined becoming: First encounters of planners beyond the plan, Planning Theory, 15(1), pp. 42-67.

Coffey, A. \& Atkinson, P. (1996) Making sense of qualitative data (Thousand Oaks, CA: Sage).

Davoudi, S. (2012) Resilience: A bridging concept or a dead end?, Planning Theory \& Practice, 13(2), pp. 299-307.

Davoudi, S., Brooks, E. \& Mehmood, A. (2013) Evolutionary resilience and strategies for climate adaptation, Planning Practice \& Research, 28(3), pp. 307-322.

Davy, B. (2008) Plan it without a condom!, Planning Theory, 7(3), pp. 301-317.

Davy, B. (2012) Land policy: Planning and the spatial consequences of property (London \& New York, NY: Routledge).

De Roo, G. \& Boelens, L. (2016) Setting the scene-About planning and a world in change, in: G. De Roo \& L. Boelens (Eds) Spatial planning in a complex unpredictable world of change: Towards a proactive co-evolutionary type of planning within the Eurodelta, pp. 14-27 (Groningen: InPlanning).

Douglas, M. (1973) Natural symbols: Explorations in cosmology, 2nd ed. (London: Barrie \& Jenkins).

Douglas, M. (1978) Cultural bias (London: Royal Anthropological Institute of Great Britain and Ireland).

Eilstein, H. (1997) Life contemplated, life practical: An essay on fatalism (Amsterdam \& Atlanta, GA: Rodopi).

Etzioni, A. (1967) Mixed-scanning: A “third” approach to decision-making, Public Administration Review, 27(5), pp. 385-392.

Giezen, M., Bertolini, L. \& Salet, W. (2014) Adaptive capacity within a mega project: A case study on planning and decision-making in the face of complexity, European Planning Studies, 27(5), pp. 999-1018.

Grint, K. (2010) Wicked problems and clumsy solutions: The role of leadership, in: S. Brookes \& K. Grint (Eds) The new public leadership challenge, pp. 169-186 (London: Palgrave Macmillan). 
Hartmann, T. (2011) Clumsy floodplains: Responsive land policy for extreme floods (Farnham: Ashgate).

Hartmann, T. (2012) Wicked problems and clumsy solutions: Planning as expectation management, Planning Theory, 11(3), pp. 242-256.

Hartmann, T. \& Hengstermann, A. (2014) Territorial cohesion through spatial policies: An analysis with cultural theory and clumsy solutions, Central European Journal of Public Policy, 8(1), pp. 30-49.

Hendriks, F. (1999) Post-industrialising city: Political and cultural biases, GeoJournal, 47(3), pp. 425-432.

Holling, C. S. (2001) Understanding the complexity of economic, ecological, and social systems, Ecosystems, 4(5), pp. 390-405.

Hood, C. (2002) The art of the state: Culture, rhetoric, and public management (Oxford: Clarendon Press).

Kuusisto-Arponen, A-K., Laine, M. \& Rauhala, M. (2014) Osallistumisen odotusten kurimus: Narratiivinen analyysi paikallisesta maankäytön konfliktista [A maelstrom of expectations: Narrative analysis of participation in local land use conflict], Finnish Journal of Urban Studies, 52(4), pp. 11-33.

Kvale, S. \& Brinkmann, S. (2009) InterViews: Learning the craft of qualitative research interviewing (Thousand Oaks, CA: Sage).

Majoor, S. (2015) Resilient practices: A paradox-oriented approach for large-scale development projects, Town Planning Review, 86(3), pp. 257-277.

Mamadouh, V. (1999) Grid-group cultural theory: An introduction, GeoJournal, 47(3), pp. 395-409.

March, J. (1991) Exploration and exploitation in organizational learning, Organization Science, 2(1), pp. 71-87.

Ministry of the Environment (2014) Arviointi maankäyttö- ja rakennuslain toimivuudesta 2013 [Assessment of the effectiveness of the Land Use and Building Act in 2013] Finnish environment 1/2014, Helsinki: Ministry of the Environment.

Oosterlynck, S. (Ed) (2011) Strategic spatial projects: Catalysts for change (London: Routledge).

Porter, L. \& Davoudi, S. (2012) The politics of resilience for planning: A cautionary note, Planning Theory \& Practice, 13(2), pp. 329-333. 
Savini, F., Salet, W. \& Majoor, S. (2015) Dilemmas of planning: Intervention, regulation, and investment, Planning Theory, 14(3), pp. 296-315.

Savini, F. \& Salet, W. (Eds) (2017) Planning projects in transition. Interventions, regulations and investments (Berlin: Jovis).

Schmitt, S-M. \& Hartmann, T. (2016) Clumsy city by design —A theory for Jane Jacobs' imperfect cities?, Urban Planning, 1(4), pp. 42-50.

Schön, D. (1983) The reflective practitioner (New York; NY: Basic Books).

Solomon, R. C. (2003) On fate and fatalism, Philosophy East and West, 53(4), pp. 435454.

Thompson, M. \& Beck, M. B. (2015) Coping with change: Urban resilience, sustainability, adaptability and path dependence Future of cities: working paper, UK Government's Foresight Future of Cities Project.

Thompson, M., Ellis, R. \& Wildavsky, A. (1990) Cultural Theory (Boulder, CO: Westview Press).

Van Assche, K., Beunen, R. \& Duineveld, M. (2017) Co-evolutionary planning theory: Evolutionary governance theory and its relatives, in: M. Gunder, A. Madanipour \& V. Watson (Eds) The Routledge handbook of planning theory, pp. 221-234 (New York, NY: Routledge).

Verweij, M., Douglas, M., Ellis, R., Engel, C., Hendriks, F., Lohmann, S., Ney, S., Rayner, S. \& Thompson, M. (2006) The case for clumsiness, in: M. Verweij \& M. Thompson (Eds) Clumsy solutions for a complex world: Governance, politics and plural perceptions, pp. 1-27 (Hampshire: Palgrave Macmillan).

Yin, R. K. (2014) Case study research: Design and methods, 5th ed. (Thousand Oaks, CA: Sage). 


\section{Appendices}

\section{Appendix 1. Interviews}

\begin{tabular}{|l|l|}
\hline Organization & Date \\
\hline City of Oulu, Urban and Environmental Services (3 persons) & 14 January 2014 \\
\hline City of Oulu, Urban and Environmental Services & 21 February 2014 \\
\hline City of Oulu, Urban and Environmental Services & 24 February 2014 \\
\hline City of Oulu, Urban and Environmental Services & 26 February 2014 \\
\hline City of Oulu, Urban and Environmental Services & 17 March 2014 \\
\hline $\begin{array}{l}\text { City of Oulu, Urban and Environmental Services, Educational and } \\
\text { Cultural services, Kaukovainio District Board (a workshop of 5 } \\
\text { persons) }\end{array}$ & 5 January 2015 \\
\hline City of Oulu, Urban and Environmental Services & \\
\hline City of Oulu, Educational and Cultural Services & 5 December 2016 \\
\hline City of Oulu, Urban and Environmental Services & 15 December 2016 \\
\hline Kaukovainio District Board & 15 December 2016 \\
\hline City of Oulu, Urban and Environmental Services & 9 January 2017 \\
\hline City of Oulu, Urban and Environmental Services & 12 January 2017 \\
\hline Kaukovainio District Board & 12 January 2017 \\
\hline Oulun Sivakka (City-owned Real Estate Company) & 20 January 2017 \\
\hline City of Oulu, Educational and Cultural Services & 7 February 2017 \\
\hline Construction company, developer in Kaukovainio Center project & 3 February 2017 \\
\hline
\end{tabular}

\section{Appendix 2. Planning Documents}

City of Oulu (2010-2012) Assignments and outcomes of the participatory planning workshops in Kaukovainio in 17.4.2010, 13.10.2010, 2.3.2011 and 25.1.2012. Available at https://www.ouka.fi/oulu/kaupunkisuunnittelu/kaukovainio (Accessed 2 November 2019).

City of Oulu (2011) Oulun keskeisen kaupunkialueen täydennysrakentamisselvitys [Infill development survey for the central areas of Oulu]. Available at https://www.ouka.fi/c/document_library/get_file?uuid=167f4c96-79e3-47188fc7-43494f84acf5\&groupId=64220 (Accessed 2 November 2019).

City of Oulu (2013) Kaukovainion maankäytön, liikenteen ja ympäristön yleissuunnitelma 2012 [Kaukovainio general plan for land use, transportation and environment 2012]. Available at 
https://www.ouka.fi/documents/64220/158009/Loppuraportti_260313_nettiversi o.pdf/f96443e6-f6dc-49c8-8cf4-a43177a94e45 (Accessed 2 November 2019).

City of Oulu (2014) Oulun kaupungin maapoliittiset linjaukset [Land policy guidelines for the City of Oulu]. Available at https://www.ouka.fi/c/document_library/get_file?uuid=ab06aad1-cf19-4bd8842b-34effb07ac03\&groupId=52058 (Accessed 2 November 2019).

City of Oulu (2014) Kaukovainion keskuksen yleissuunnitelma [Kaukovainio Center general plan]. Available at oulu.ouka.fi/tekninen/Suunnitelmat/Nayta_Liite.asp?ID=4539\&Liite=yleissuunn itelmaraportti_A3.pdf (Accessed 2 November 2019).

City of Oulu (2016) Uuden Oulun yleiskaava, kaavaselostus [New Oulu master plan, plan report]. Available at: https://www.ouka.fi/c/document_library/get_file?uuid=99ef693d-9341-4c05884a-e673691d0769\&groupId=64220 (Accessed 2 November 2019).

City of Oulu (2017) Asemakaavan selostus, Kaukovainion keskus [Plan report, Kaukovainio Center local detailed plan]. Available at oulu.ouka.fi/tekninen/Suunnitelmat/Nayta_Liite.asp?ID=6361\&Liite=Selostus_ voimaantullut.pdf (Accessed 2 November 2019).

The Housing Finance and Development Centre of Finland (2015) Tutkitusti parempi lähiö: Asuinalueiden kehittämisohjelman loppuraportti [Development program for residential areas, final report], Helsinki: The Housing Finance and Development Centre of Finland. 


\section{Tables}

Table 1. Challenges of the fatalistic planning rationale.

\begin{tabular}{|l|l|l|}
\hline $\begin{array}{l}\text { Planning phase of } \\
\text { development }\end{array}$ & Challenge of fatalism & Suggested solution \\
\hline General infill development plan & $\begin{array}{l}\text { Fatalism is not embraced } \\
\text { because of its passiveness }\end{array}$ & $\begin{array}{l}\text { Appreciate the high grid- } \\
\text { dimension of fatalism as an } \\
\text { opportunity to acknowledge the } \\
\text { uncertainty of the future }\end{array}$ \\
\hline Kaukovainio Center project & Fatalism results in inaction & $\begin{array}{l}\text { Complement the low group- } \\
\text { dimension of fatalism with the } \\
\text { three active rationales }\end{array}$ \\
\hline Urban renewal program & Fatalism is viewed as \\
indifference & $\begin{array}{l}\text { Communicate high grid- } \\
\text { dimension as the opportunity of } \\
\text { the fatalistic planning rationale, } \\
\text { and low group-dimension as the } \\
\text { challenge }\end{array}$ \\
\hline
\end{tabular}




\section{Figures}

Figure 1. The four rationales connected to urban planning (based on Hendriks (1999),

Davy (2008; 2012), Hartmann (2011; 2012), and Hartmann \& Hengstermann (2014)).

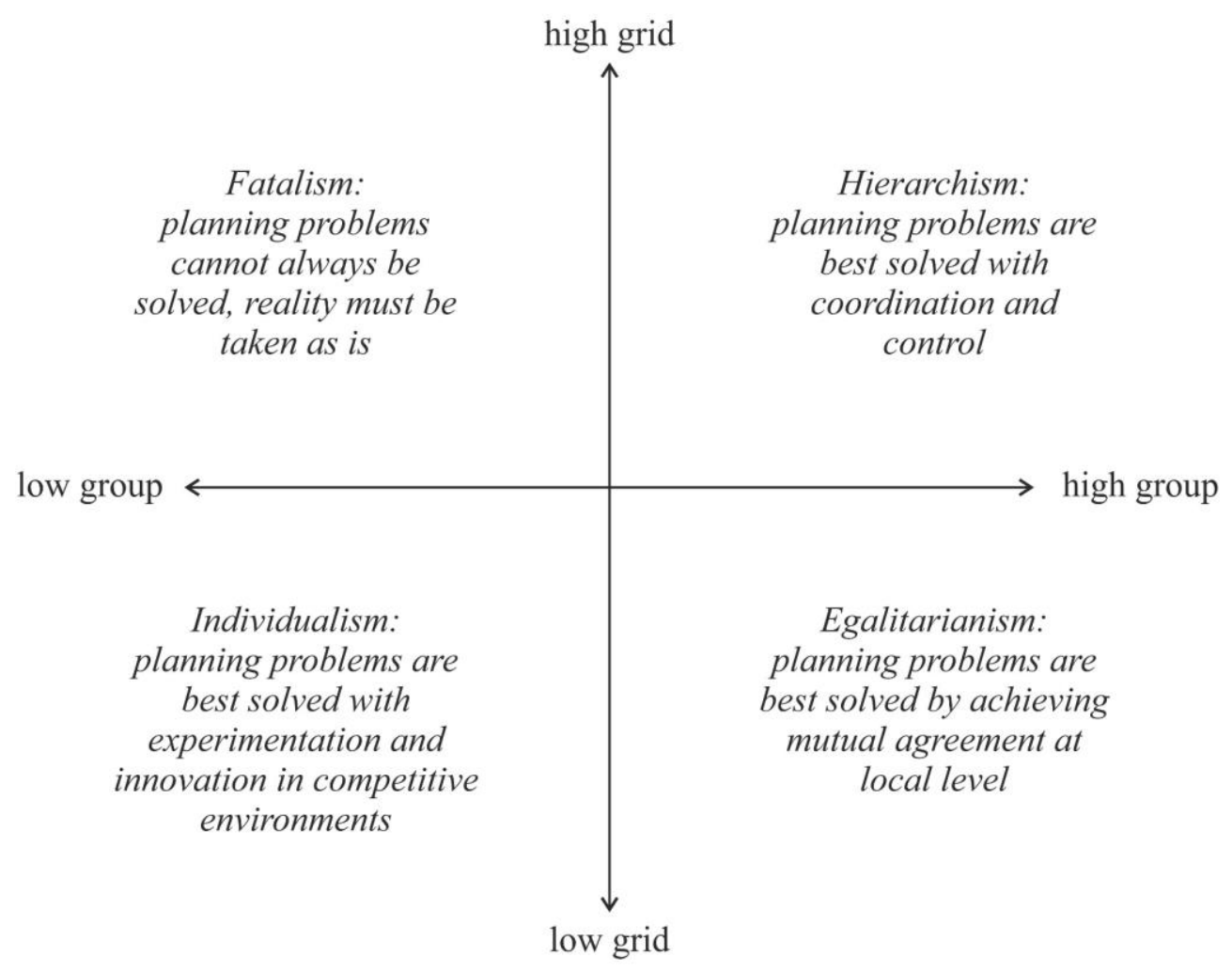

